\title{
Gulf of Mexico Climate-History Calibration Study
}

Reliable instrumental records of past climate are available for about the last 150 years only. To supplement the instrumental record, reconstructions of past climate are made from natural recorders such as trees, ice, corals, and microfossils preserved in sediments. These proxy records provide information on the rate and magnitude of past climate variability, factors that are critical to distinguishing between natural and human-induced climate change in the present. However, the value of proxy records is heavily dependent on calibration between the chemistry of the natural recorder and of the modern environmental conditions. The Gulf of Mexico Climate and Environmental History Project is currently undertaking a climate-history calibration study with material collected from an automated sediment trap. The primary focus of the calibration study is to provide a better calibration of low-latitude environmental conditions and shell chemistry of calcareous microfossils, such as planktic Foraminifera.

Planktic Foraminifera are microscopic, unicellular organisms that secrete a calcium carbonate shell that records the conditions of their ocean habitat. For example, the temperature of the ocean affects the ratio of magnesium $(\mathrm{Mg})$ to calcium $(\mathrm{Ca})$ in Foraminifera shells, such that more $\mathrm{Mg}$ is incorporated in the shell during the summer than during the winter. The most widely used species in low-latitude climate reconstructions, Globigerinoides ruber (fig. 1), is considered to dwell between the ocean surface and 50 meters (m) of water depth, year-round. Analysis of $\mathrm{Mg} / \mathrm{Ca}$ in shells of Globigerinoides ruber that settle on the ocean floor provides researchers with a history of the mean annual sea-surface conditions.

In early January 2008, researchers from the U.S. Geological Survey (USGS) deployed a McLane Mark 78 automated sediment trap

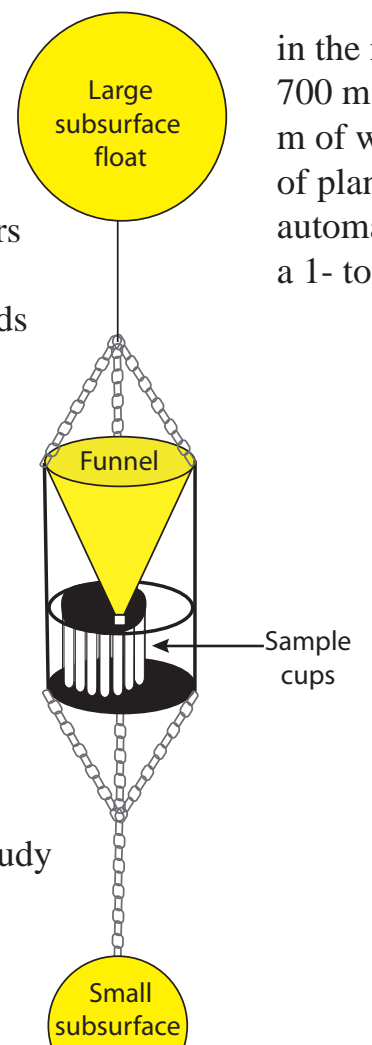

in the northern Gulf of Mexico (fig. 2). The trap is positioned at $700 \mathrm{~m}$ of water depth on the mooring, which is anchored in $\sim 1,150$ $\mathrm{m}$ of water, to guarantee the collection of deeper dwelling species of planktic Foraminifera. The trap includes 21 sample cups that automatically rotate on a gear plate, such that each cup represents a 1- to 2-week collection period.

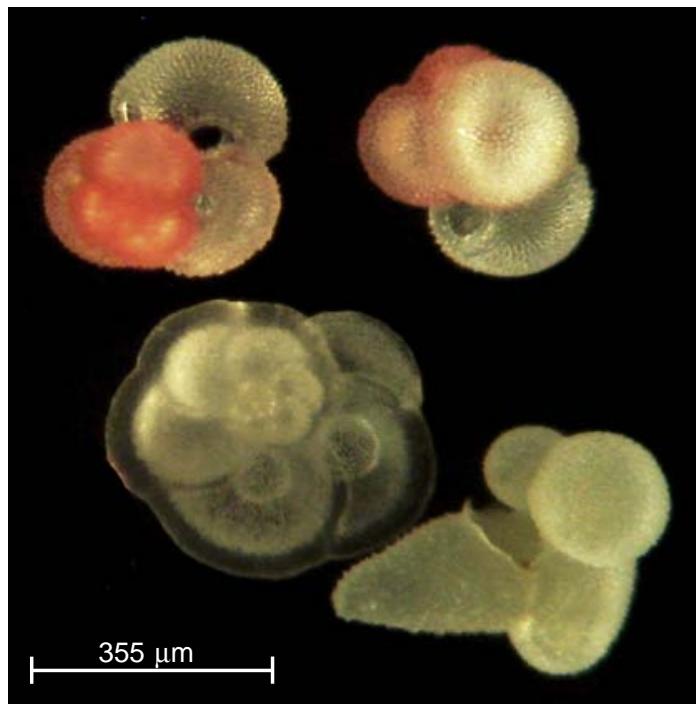

Figure 1. Photograph of planktic Foraminifera collected from the sediment trap. Top row: Globigerinoides ruber (pink variety); bottom left: Globorotalia menardii; bottom right: Globigerina digitata. $\mu \mathrm{m}$, micrometer. Photo credit: Jessica Spear, USGS.

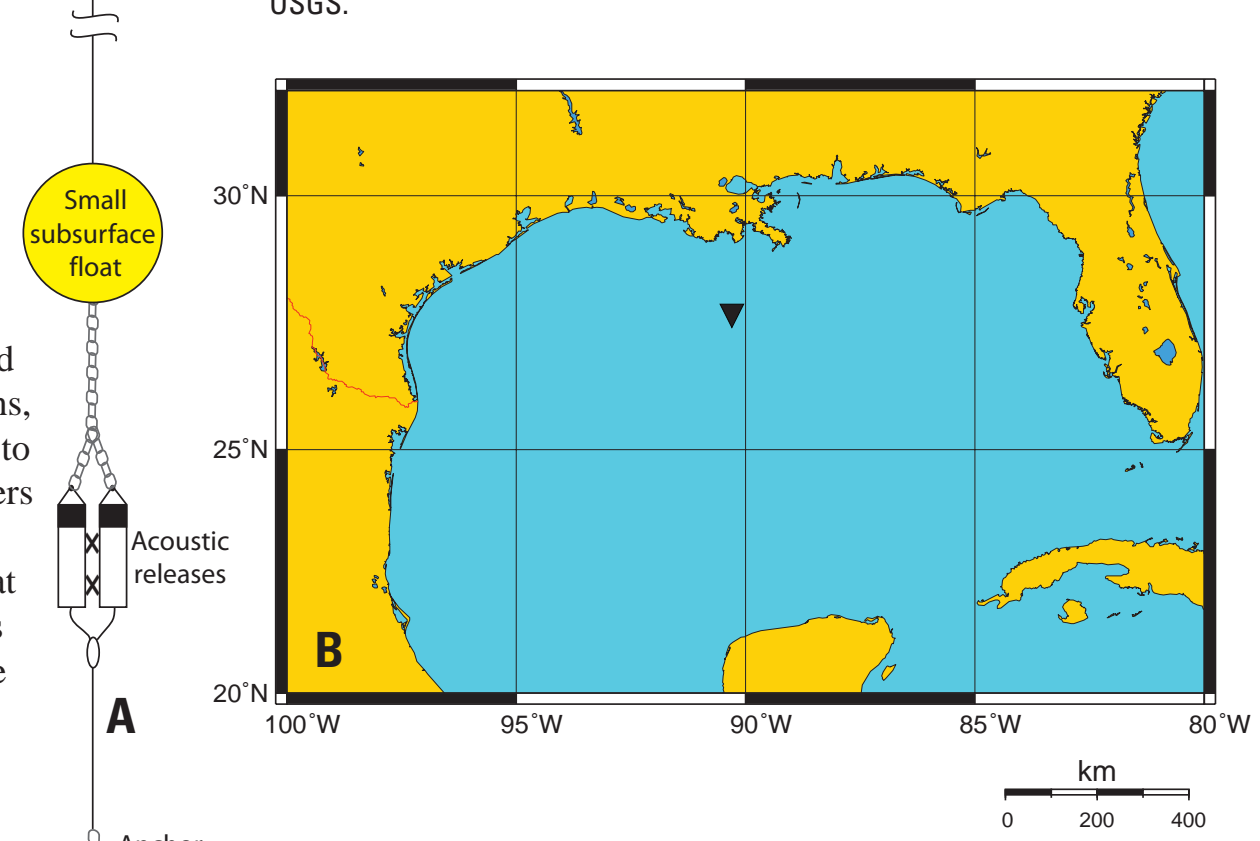

Figure 2. (A) Schematic of the sediment-trap mooring and its location (B) (inverted triangle) at $27^{\circ} 30.996 \mathrm{~N}$. and $90^{\circ} 21.388 \mathrm{~W}$. 


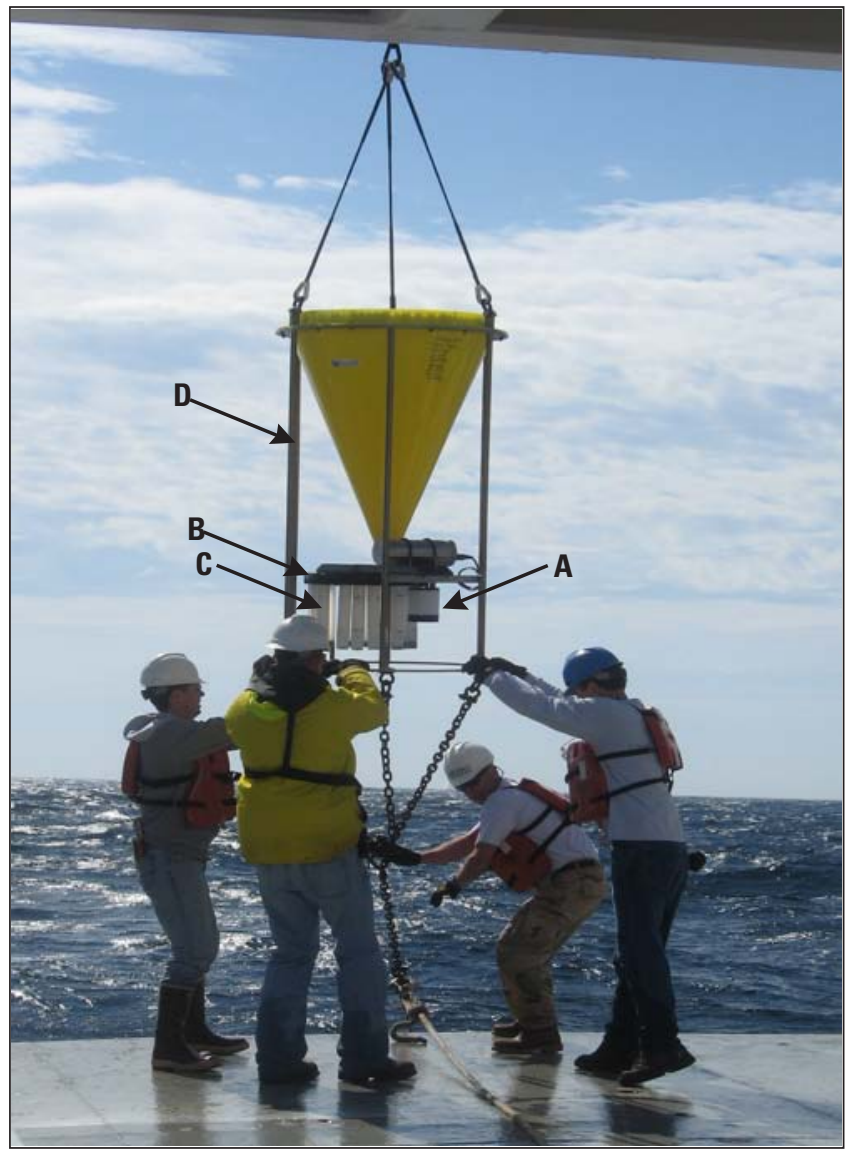

Figure 3. Recovery of the sediment-trap mooring, including the electronic stepping motor $(A)$, the gear plate $(B)$, and the attached sample cups (C), all situated on a titanium frame (D). Photo credit: Jessica Spear, USGS.
When the trap is serviced every 3 to 6 months (figs. 3 and 4), conductivity-temperature-depth (CTD) measurements are conducted to provide profiles of temperature and salinity that will be used for the modern calibration. The modern calibration can then be applied to records from deep-sea sediments collected in the northern Gulf of Mexico over longer timescales (fig. 5).

In addition to providing material for the modern $\mathrm{Mg} / \mathrm{Ca}$ shell calibration, the sediment-trap samples are providing new information on seasonal changes in the flux and composition of Gulf of Mexico Foraminifera assemblages.

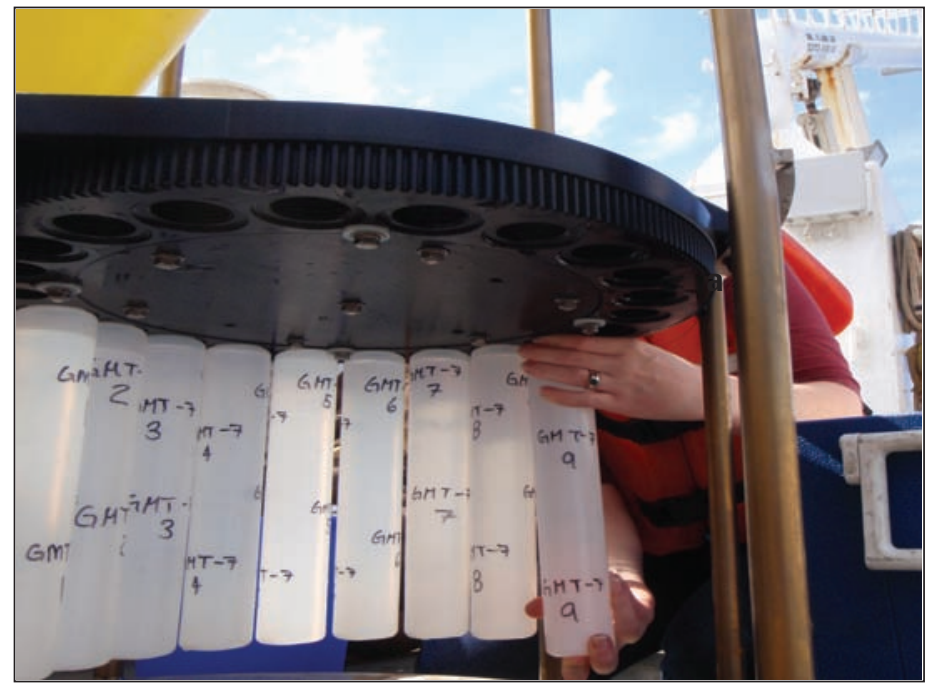

Figure 4. A geologist attaching new sample cups on the gear plate. Photo credit: Chris Reich, USGS.

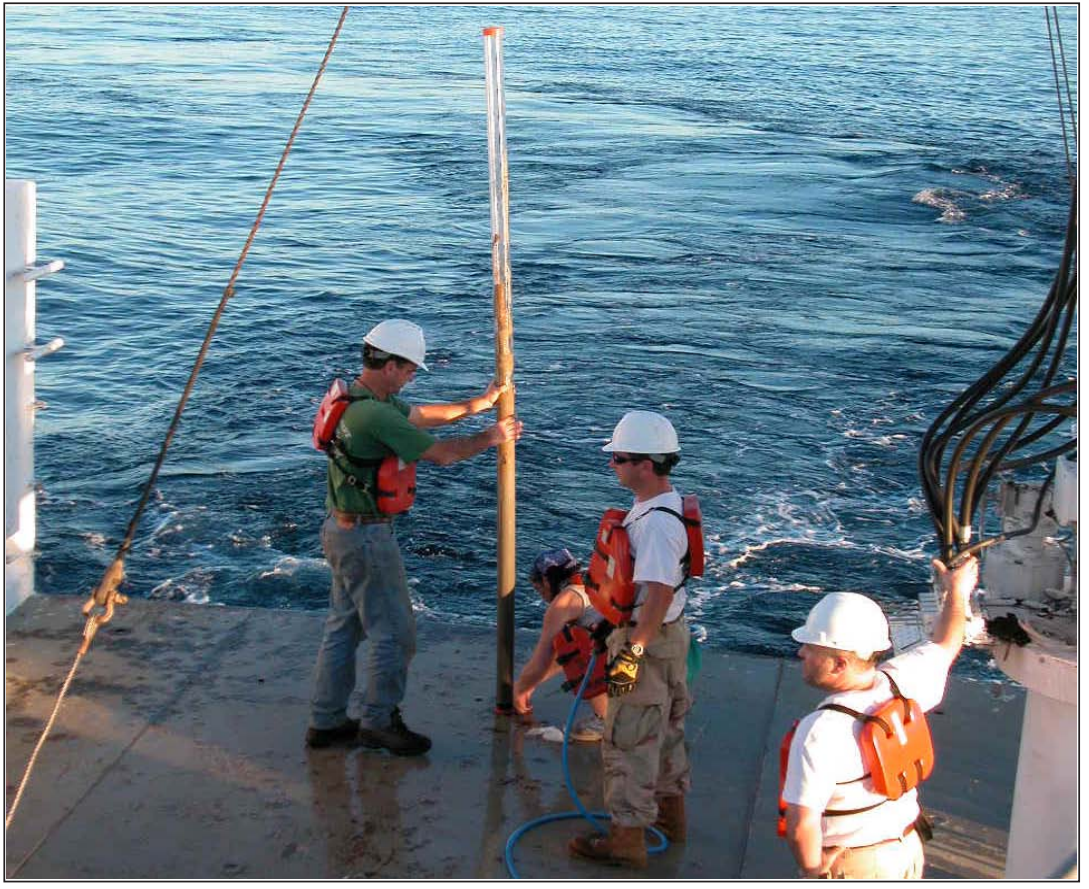

Figure 5. Recovery of deep-sea sediments from near the sediment-trap mooring location in the northern Gulf of Mexico. Photo credit: Lisa Osterman, USGS.

\section{Contact Information}

Jessica W. Spear

Geologist

U.S. Geological Survey

St. Petersburg Coastal and Marine Science Center 600 4th Street South St. Petersburg, FL 33701

PH: (727) 803-8747 x3042

FAX: (727) 803-2031

Email: jspear@usgs.gov

Richard Z. Poore

Geologist

\section{U.S. Geological Survey}

St. Petersburg Coastal and Marine Science Center 600 4th Street South St. Petersburg, FL 33701

PH: (727) 803-8747 x3131

FAX: (727) 803-2031

Email: rpoore@usgs.gov

http://coastal.er.usgs.gov/gom/

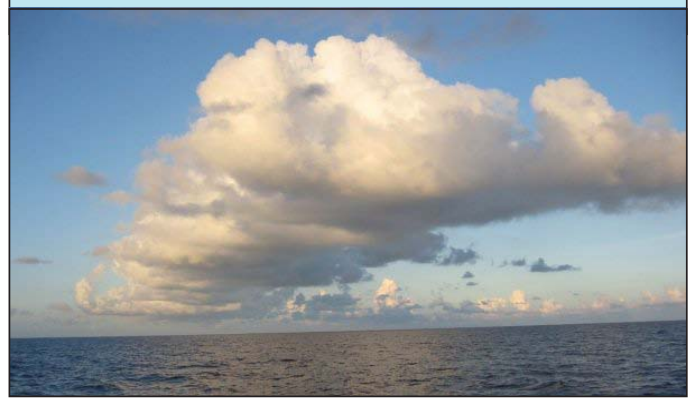

